Firat University Journal of Experimental and
Computational Engineering
Firat Üniversitesi Deneysel ve Hesaplamalı
nand compuation
Enginering

\title{
Modeling of a solar air collector heat transfer coefficient with regression algorithms
}

\section{Bir havalı güneş kollektörü ısı transfer katsayısının regresyon algoritmaları ile modellenmesi}

\author{
Ebru Kavak AKPINAR ${ }^{1 *}$ (D), Mehmet DAŞ ${ }^{2}$ iD
}

\begin{abstract}
${ }^{1}$ Department of Mechanical Engineering, Faculty of Engineering, Firat University, Elaziğ, Turkiye. ${ }^{2}$ Department of Mechanical Engineering, Faculty of Architecture and Engineering, Tokat Gaziosmanpasa University, Tokat, Turkiye. ${ }^{1}$ ebruakpinar@firat.edu.tr, ${ }^{2}$ mehmet.das@ gop.edu.tr
\end{abstract}

\begin{abstract}
Solar air collectors (SAC) are thermodynamic systems that convert solar energy into useful fluid energy. SACs are very common in heating, cooling, food drying, and many other low-temperature applications. In this study, the heat transfer coefficient in the SAC was calculated according to Newton's cooling law. The obtained values and the thermal performance of the SAC were examined during the sunshine period. At the same time, SAC heat transfer coefficient models were made with the help of regression algorithms (multiple linear regression, simple linear regression) using SAC temperature data obtained by experimental measurements (inlet fluid, outlet fluid, and absorber plate) and solar radiation data on the SAC. As a result of the modeling, linear mathematical equations expressing the heat transfer coefficient for SACs were obtained. Obtained experimental and model data were compared. SAC heat transfer coefficient values were modeled with a mean absolute error of 0.6.
\end{abstract}

Keywords: Solar air collector, Heat transfer coefficient, Solar energy, Regression, Equation derivation

Özet

Havalı güneş kollektörleri (HGK), güneş enerjisini faydalı akışkan enerjisine dönüştüren termodinamik sistemlerdir. Isıtmada, soğutmada, gıda kurutmada ve daha birçok düşük sıcaklık uygulamalarında HGK'ların kullanımı oldukça yaygındır. Bu çalışmada HGK içerisindeki 1sı transfer katsayısı Newton soğutma kanununa göre hesaplanmış ve elde edilen değerler ile HGK'nın termal performansı güneşlenme süresi boyunca incelenmiştir. Aynı zamanda deneysel ölçümler ile elde edilen HGK sıcaklık verileri (giriş akışkan, çıkış akışkan ve yutucu plaka) ve kollektör üzerine gelen güneş radyasyon verileri kullanılarak regresyon algoritmaları (çoklu liner regresyon, basit liner regresyon) yardımıyla HGK 1sı transfer katsayısı modellemeleri yapılmıştır. Modellemeler sonucu HGK lar için 1sı transferi katsayısını ifade eden doğrusal matematiksel eşitlikler elde edilmiştir. Elde edilen deneysel ve model verileri karşılaştırılmıştır. HGK 1Sı transferi katsayısı değerleri 0.6 ortalama mutlak hata değeri ile modellenmiştir.

Anahtar kelimeler: Havalı güneş kollektörü, Isı transfer katsayısı, Güneş enerjisi, Regresyon, Eşitlik üretme

\section{Introduction}

One of the most important components of solar energy systems is undoubtedly flat plate type solar collectors. Solar collectors are system elements that collect the usable energy from the sun and transmit it to another environment using various fluids [1]. Among flat plate type solar collectors, the usage areas of SAC type collectors are pretty comprehensive. The SACs, which are used primarily in food drying [2,3] and space heating [4], are preferred as an alternative energy method due to the gradual depletion of fossil fuels and the harmful environmental effects of fuels [5]. The working principle of SACs is quite simple. When the sun's rays come to the SAC collector absorber surface, the absorber plate heats up, and this heat is transferred to the air passing over the plate, thereby heating the collector outlet air [6]. In the SACs, there is a heat transfer between the absorber plate and the fluid, and this heat transfer takes place by convection heat transfer (h) according to Newton's cooling law [7,8].

Many data are obtained as a result of experimental studies. Various calculations and models are created with this data. Models produced with experimental data are a structure that allows the data to be observed better. A model with a

${ }^{*}$ Corresponding author 
theoretical framework helps to understand a particular phenomenon better. The linear model is of primary importance in the education of any theoretical or applied mathematician. Linear statistical models are widely used in engineering and other science fields as part of these processes [9]. There are many studies in the literature modeling the thermal efficiency of SAC with MLR [10-13]. When these studies are examined, there are temperature and radiation values in the data set created to model SAC thermal efficiency.

In this study, the heat transfer coefficient of SAC was calculated using experimental data. The data set used in the calculations was also modeled with regression algorithms, and mathematical equations were produced for the $h$ values. Linear mathematical equations expressing two $\mathrm{h}$ values were obtained with multiple and simple regression algorithms. The $h$ values obtained by the models were compared with the experimental $h$ values. The regression equation that best expresses the $\mathrm{h}$ coefficient used for the heat transfer in SAC was determined.

\section{Materials and Methot}

The dimensions of the SAC used in the experiments are $1400 \mathrm{~mm} \times 800 \times 150 \mathrm{~mm}$. The SAC structure consists of a transparent cover, absorber plate, flat plate, insulation layer, and outer casing. The SAC consists of $12 \mathrm{~mm}$ thick tempered glass as transparent cover and $0.5 \mathrm{~mm}$ thick matt-black painted corrugated stainless-steel sheet as absorber plate. In SAC, $4 \mathrm{~cm}$ thick rock wool was used as insulation material, and $4 \mathrm{~mm}$ thick aluminum was used as outer casing material. A radial fan $\left(0.15 \mathrm{~m}^{3} / \mathrm{h}, 0.18 \mathrm{~kW}, 220 \mathrm{~V}, 50 \mathrm{~Hz}, 2800 \mathrm{rpm}\right)$ connected to the air inlet parts of the SAC with a hood provided the necessary air. The materials and properties of the SAC system are given in Table 1 . The view of the experimental setup is shown in Figure 1.

The measurements were carried out in June 2018 under the climatic conditions of Elazig province. In the experiments, collector inlet temperature, collector outlet temperature, panel glass temperature, panel ground temperature, and solar radiation values were measured at intervals of 30 minutes. Waterproof DS18B20 digital temperature sensors and pyranometer are used for these measuring points. The experiments were carried out at a constant air velocity of $0.18 \mathrm{~m} / \mathrm{s}$ and a constant mass airflow rate of $0.023 \mathrm{~kg} / \mathrm{s}$. The experiments carried out on 1-2 June were started at 08:00 and ended at 18:00.

$\mathrm{J}$ type iron-constantan thermocouples, manually controlled 20-channel automatic digital thermometer (ELIMKO, 6400) in the measurements of collector inlet temperature $\left(\mathrm{T}_{\mathrm{i}}\right)$, collector outlet temperature $\left(\mathrm{T}_{\mathrm{o}}\right)$, collector absorber plate temperature $\left(\mathrm{T}_{\mathrm{yp}}\right)$, collector ground temperature $\left(\mathrm{T}_{\mathrm{ta}}\right)$ with a reading accuracy of $\pm 0.1^{\circ} \mathrm{C}$. Collector outlet air velocity was measured with a $0-15 \mathrm{~m} / \mathrm{s}$ digital anemometer (LUTRON, AM-4201) with a reading accuracy of $\pm 0.01 \mathrm{~m} / \mathrm{s}$. While the system was operating, the solar radiation was measured with a sensitivity of $\pm 0.1 \mathrm{~W} / \mathrm{m}^{2}$ and a Kipp and Zonen pyranometer in a CC12 model digital solar integrator. Collector measurement points are shown schematically in Figure 2. 

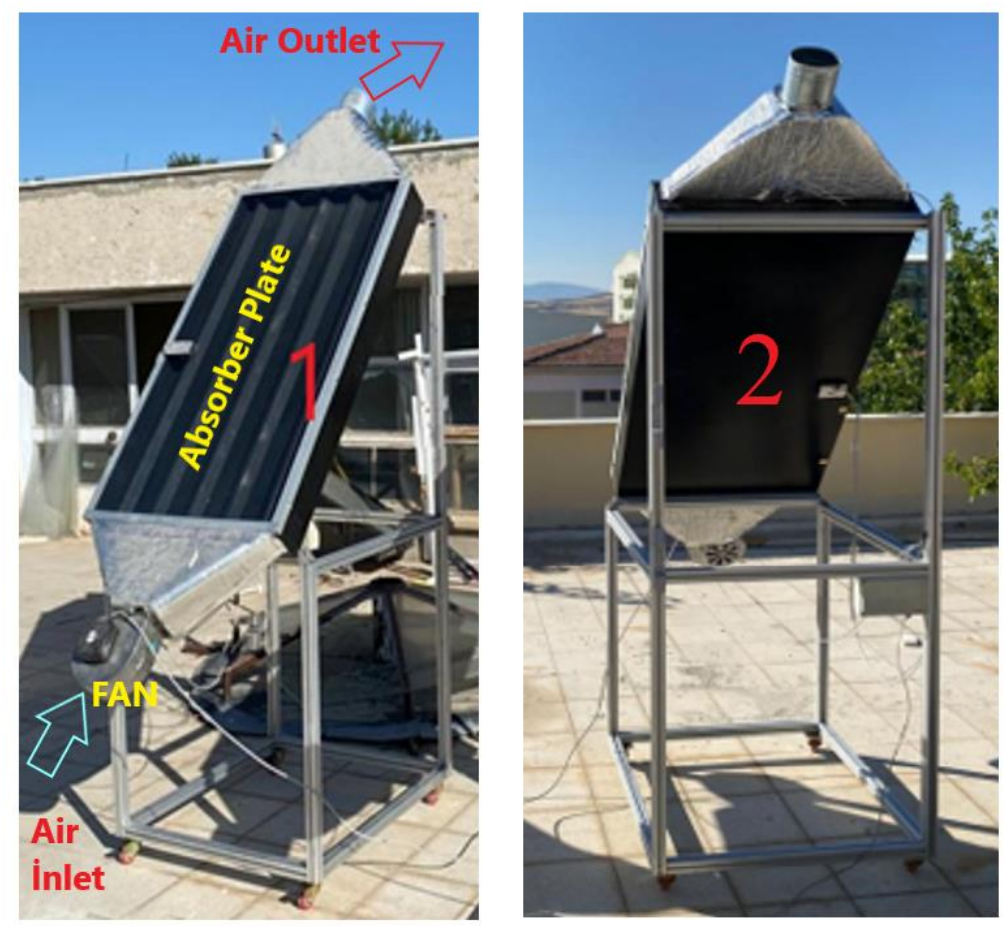

Figure 1. Front (1) and rear (2) view of SAC

Table 1. Experimental set components

\begin{tabular}{ll}
\hline Part & Materials and Components \\
\hline SAC case & $4 \mathrm{~mm}$ aluminum thickness, $1400 \times 800 \times 150 \mathrm{~mm}$ \\
Transparent Cover & $12 \mathrm{~mm}$ thick tempered glass \\
Absorber Plate & $0.5 \mathrm{~mm}$ aluminum thickness, $1400 \times 800 \mathrm{~mm}$ \\
Insulation Material & $3,5 \mathrm{~kg}$ rock wool, thickness $4 \mathrm{~cm}$ \\
Circulation Fan & Stainless steel, $\left(0.15 \mathrm{~m}^{3} / \mathrm{h}, 0.18 \mathrm{~kW}, 220 \mathrm{~V}, 50 \mathrm{~Hz}, 2800 \mathrm{rpm}\right)$ \\
\hline
\end{tabular}

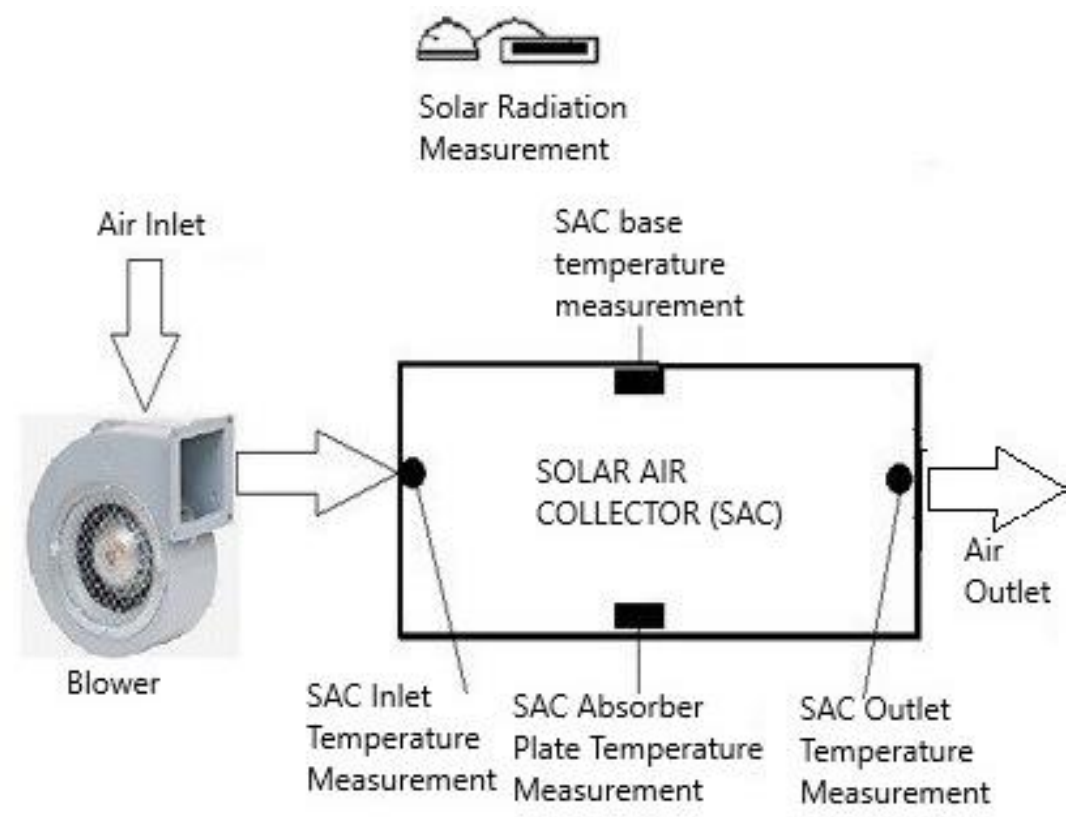

Figure 2. Schematic representation of collector measuring points 


\section{Uncertainty Analysis}

It has been estimated that both fixed errors, manufacturing errors and random errors are effective for the uncertainties that will arise during the measurement of temperature, air velocity and solar radiation in the SAC. When measuring the value of a parameter, fixed errors, random errors, and errors due to manufacturing errors need to be considered. Equation 1 was used to calculate the total errors resulting from these measured values [14].

$W_{x}=\left[\left(X_{1}\right)^{2}+\left(X_{2}\right)^{2}+\cdots \ldots \ldots\left(X_{n}\right)^{2}\right]^{1 / 2}$

\section{Theoretical Calculations}

SAC transforms solar energy into usable energy, increasing the heat energy of the fluid passing through it. The SACs work similarly to the working principle of heat exchangers. Solar radiation is transformed into useful fluid heat $(\mathrm{Qu})$ through the SAC absorber plate. Qu is calculated with the help of the following equations $[15,16]$.

$\dot{Q}_{u}=\dot{m}_{a} C_{p a}\left(T_{o}-T_{i}\right)$

The useful heat gained by the solar collector is the same as the heat transferred to the working fluid by convection [17]. In this case, Equation 2 can also be expressed by Equation 3.

$\dot{Q}_{u}=h A_{c}\left(T_{y p}-T_{o r t}\right)$

The heat transfer coefficients for SACs are calculated as follows [15].

$h=\frac{\dot{Q}_{u}}{A_{c}\left(T_{y p}-T_{a b s}\right)}$

In Equation 4, $\mathrm{T}_{\mathrm{yp}}$ is the surface temperature of the absorber plate. The $\mathrm{T}_{\mathrm{abs}}$ is the average temperature of the air used as a fluid and is obtained by averaging the inlet and outlet temperatures of the collector. All the thermophysical properties of the air are taken according to the mean temperature [18].

$T_{a b s}=\frac{\left(T_{i}+T_{o}\right)}{2}$

Table 2 shows the uncertainty values that occur during the measurements of SAC. These values are calculated according to Equation 1.

Table 2. Measurement uncertainties in the experimental set

\begin{tabular}{cc}
\hline Measurement parameters & Uncertainty Value \\
\hline $\mathrm{T}_{\mathrm{yp}}\left({ }^{\circ} \mathrm{C}\right)$ & \pm 0.50 \\
$\mathrm{~T}_{\mathrm{i}}\left({ }^{\circ} \mathrm{C}\right)$ & \pm 0.43 \\
$\mathrm{~T}_{\mathrm{o}}\left({ }^{\circ} \mathrm{C}\right)$ & \pm 0.33 \\
SAC case base temperature $\mathrm{T}_{\mathrm{ta}}\left({ }^{\circ} \mathrm{C}\right)$ & \pm 0.30 \\
Solar Radiation $\mathrm{I}\left(\mathrm{W} / \mathrm{m}^{2}\right)$ & \pm 0.41 \\
\hline
\end{tabular}




\section{Simple linear regression model}

Models the relationship between two variables in a simple linear regression (SLR) model. This modeling result can produce a simple linear equation as in Equation 6 based on a single variable [19].

$\mathrm{Y}=\alpha_{0}+\alpha_{1} \mathrm{X}+\varepsilon$

In Equation 6; Y=Response Variable (Dependent Variable), $\mathrm{X}=$ Predictive Variable (Independent Variable), $\varepsilon=$ Random Variable (Error Term).

The linearity that appears in Equation 6 is just an assumption. Some further assumptions can be added, such as the independence distribution of $\mathrm{Y}$. The predicted model can predict the $\mathrm{Y}$ value based on a given $\mathrm{X}$ value.

\section{Multiple linear regression model}

In multiple linear regression (MLR), the dependent variable $\mathrm{Y}$ is sometimes affected by more than one independent variable. A linear model that relates Y to several estimators can be expressed by Equation 7 [20].

$\mathrm{Y}=\alpha_{0}+\alpha_{1} \mathrm{X}_{1}+\alpha_{2} \mathrm{X}_{2}+\ldots \ldots+\alpha_{\mathrm{i}} \mathrm{X}_{\mathrm{i}}+\varepsilon$

Arbitrary constants $(\alpha)$ are called regression coefficients. The error term $\alpha$ provides random variation in $Y$ that predictors cannot explain. Here, multiple variables $\left(\mathrm{X}_{1}, \mathrm{X}_{2}, \ldots \mathrm{X}_{\mathrm{i}}\right)$ can be used to estimate the $\mathrm{Y}$ value.

The data set used in the regression algorithms for the SAC heat transfer coefficient (h) values are shown in Table 3. The maximum and minimum values of the parameters resulting from the experimental measurements are given in the table.

Table3. Input and output parameters for regression models

\begin{tabular}{|c|c|c|c|}
\hline \multicolumn{4}{|c|}{ Input Parameters } \\
\hline Parameter & Unit & Min. & Max. \\
\hline$T_{i}$ & ${ }^{\circ} \mathrm{C}$ & 26.8 & 35.15 \\
\hline$T_{o}$ & ${ }^{\circ} \mathrm{C}$ & 29.3 & 56.3 \\
\hline$T_{y p}$ & ${ }^{\circ} \mathrm{C}$ & 55.2 & 75.7 \\
\hline$T_{t a}$ & ${ }^{\circ} \mathrm{C}$ & 23.2 & 45.1 \\
\hline$I$ & $\mathrm{~W} / \mathrm{m}^{2}$ & 404.8 & 926.8 \\
\hline \multicolumn{4}{|c|}{ Output Parameter } \\
\hline Parameter & Unit & Min. & Max. \\
\hline SAC heat transfer coefficient (h) & $\mathrm{W} / \mathrm{m}^{2{ }^{\circ}} \mathrm{C}$ & 1.2 & 18.1 \\
\hline
\end{tabular}

In this study, predictive model equations were created using $\mathrm{h}$ values MLR and SLR regression methods. MATLAB2018b software was used to create the predictive model. A total of 252 data were used for each regression. The 210 of these data were used for input values and 42 for output values. Mean absolute percentage error (MAPE), root mean square error (RMSE) analyzes were performed to determine the accuracy between the $h$ values obtained by regression algorithms and the experimental $h$ values. The equations of the MAPE and RMSE analyzes are given below.

MAPE $=\left(\left|\frac{h_{\exp }-T_{\text {predicted }}}{T_{\exp }}\right|\right) \cdot 100$

$\mathrm{RMSE}=\sqrt{\frac{\left(P_{h}-A_{h}\right)^{2}+\ldots . .+\left(P_{h}-A_{h}\right)^{2}}{n}}$ 


\section{Results}

For the SAC heat transfer coefficient calculation, the experimental data made on 1-2 June 2018 were used. The variation of radiation values and SAC absorber plate temperature values measured in the experiments over time are given in Figure 3. According to Figure 3, both radiation and $\mathrm{T}_{\mathrm{yp}}$ values reached the highest level in the 11:30-13:30.

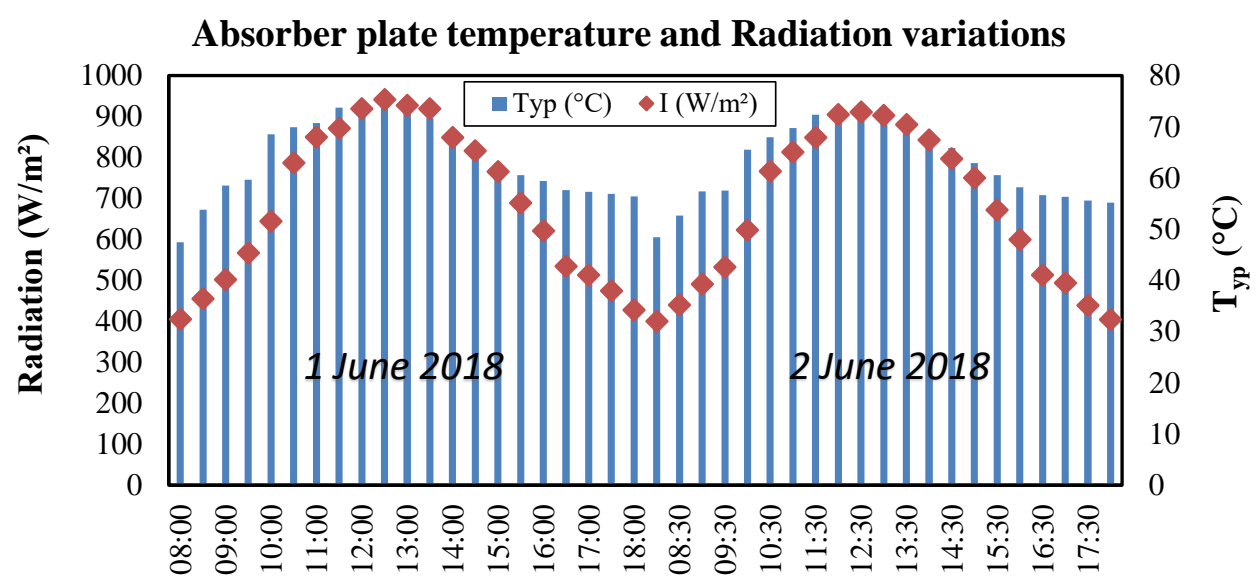

Time

Figure 3. Change of $\mathrm{SAC}$ radiation and $\mathrm{T}_{\mathrm{yp}}$ temperature values

Figure 4 shows the SAC inlet and outlet temperature difference during the experiment. According to Figure 4, where the change in the heat transfer coefficient of the SAC can also be examined, the highest temperature difference and the heat transfer coefficient value at $12: 30$ are shown as $16.7^{\circ} \mathrm{C}$ and $23.4 \mathrm{~W} / \mathrm{m} 2{ }^{\circ} \mathrm{C}$, respectively.

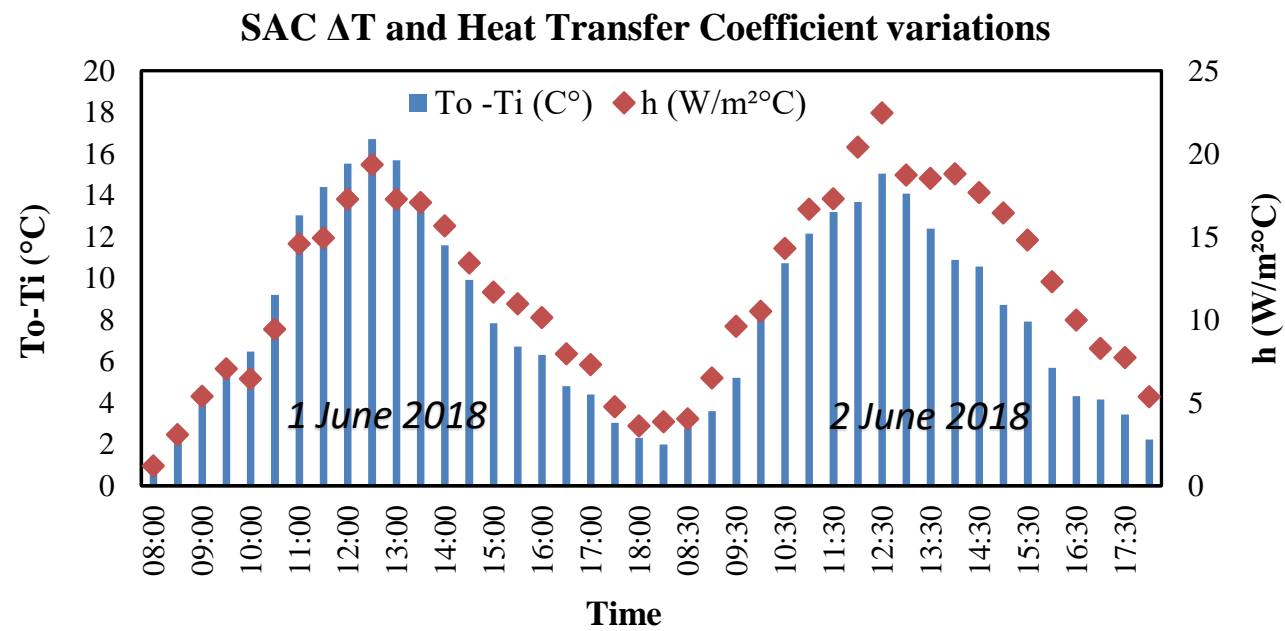

Figure 4. SAC input and output temperature difference and change of $h$ values

Table 4 shows the $h$ equations obtained by regression algorithms and the error analysis results of these equations. The $h$ equation obtained with MLR has less error value than the $h$ equation obtained with SLR. 
Table 4. SAC h equations and MAE error values obtained by regression algorithms

\begin{tabular}{|c|c|c|}
\hline MLR h Equation & MAPE & RMSE \\
\hline $\mathrm{h}\left(\mathrm{W} / \mathrm{m}^{2 \circ} \mathrm{C}\right)=0.7158 * \mathrm{~T}_{\mathrm{i}}-0.6571 * \mathrm{~T}_{\mathrm{o}}+0.2796 * \mathrm{~T}_{\mathrm{ta}}-0.3116 * \mathrm{~T}_{\mathrm{yp}}+0.0051 * \mathrm{I}-1.0629$ & 0.56 & 0.073 \\
\hline SLR h Equation & MAPE & RMSE \\
\hline $\mathrm{h}\left(\mathrm{W} / \mathrm{m}^{2 \circ} \mathrm{C}\right)=0.6 * \mathrm{~T}_{\mathrm{i}}-180.75$ & 0.94 & 0.011 \\
\hline
\end{tabular}

In studies related to SAC thermal efficiency value MLR modeling in the literature, Vafavei and Sah modeled the SAC efficiency value with an R2 value of 0.947 using MLR [10]. Caner et al. modeled the SAC efficiency value with an RMSE value of 1.2 [12] and Ghritlahre modeled the SAC efficiency value with an R2 value of 0.997 [13]. In this study, the error values of the SAC efficiency value models created with MLR are similar to the studies in the literature.

In Figures 5 and 6, the $\mathrm{h}$ values are compared as a result of the equations produced by the regression algorithms, and the experimental $\mathrm{h}$ values are given. As shown in Figure 5, the MLR $\mathrm{h}$ values are closer to the experimental $\mathrm{h}$ values.

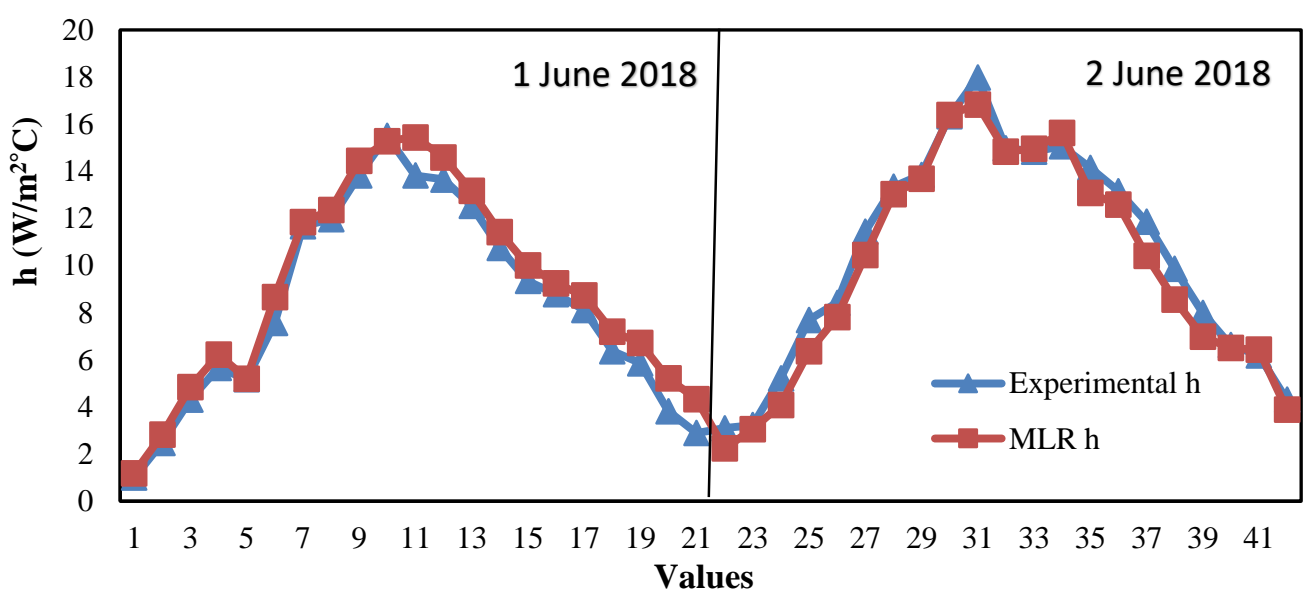

Figure 5. Comparison of SAC experimental h values and MLR h values

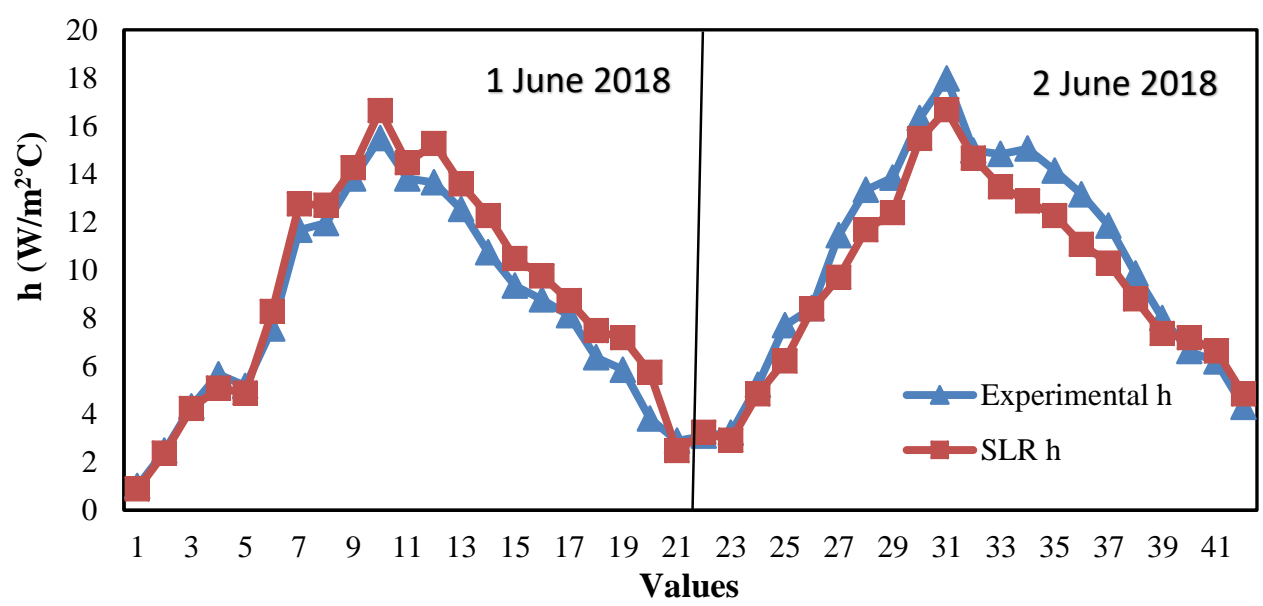

Figure 6. Comparison of SAC experimental $h$ values and SLR $h$ values 
Figure 7 shows the convergence between the $h$ values obtained by both regression algorithms and the experimental $h$ values. According to Figure 7, the regression algorithm closest to the experimental values is MLR regression.

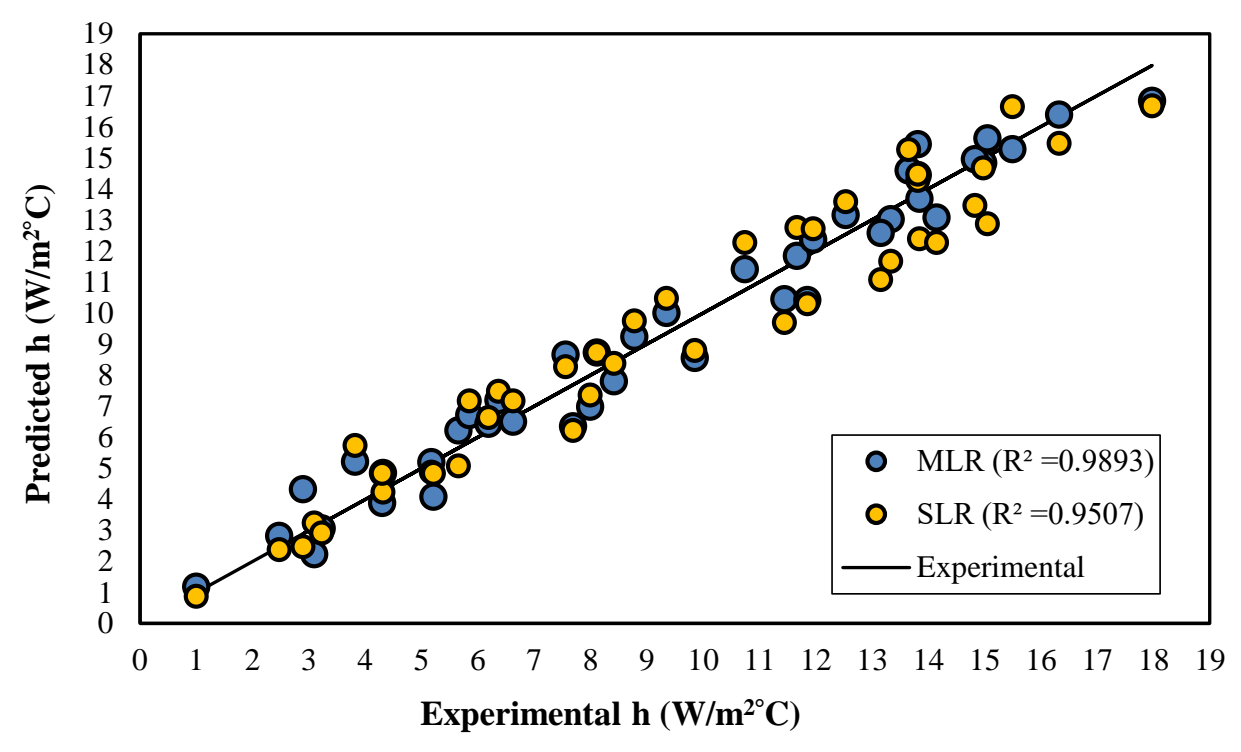

Figure 7. SAC experimental $\mathrm{h}$ values and regression $\mathrm{h}$ values convergence

\section{Conclusions}

In this study, the heat transfer coefficient values of an SAC were modeled by multiple and simple regression methods. The resulting model error result has an average absolute error value of 0.6. The values determined by the mathematical $\mathrm{h}$ equation obtained by CLR are pretty close to the experimental $h$ values. Equations with fewer error values can be obtained by using more data sets and different machine learning algorithms for the obtained model. It is hoped that the heat transfer coefficient equation obtained as a result of the study can be used in different types of collectors and different experimental conditions.

\section{Acknowledgments}

This study was supported by Firat University Scientific Research Foundation (Project Numbers MF.17.11 and MF 16.54).

\section{Author Contribution Statement}

In the study, Author 1 contributed to forming the idea, the analysis of the results, provision of the materials and examination of the results; Author 2 contributed making the design and literature review.

\section{Ethics Committee Approval and Conflict of Interest}

There is no need for an ethics committee approval in the prepared article. There is no conflict of interest with any person/institution in the prepared article.

\section{Nomenclature}

$A_{c} \quad$ SAC surface area $\left(\mathrm{m}^{2}\right)$

Avg Average

$T_{y p} \quad$ SAC absorber plate temperature $\left({ }^{\circ} \mathrm{C}\right)$ 
$C_{p a} \quad$ Air specific heat at constant pressure $(\mathrm{kJ} / \mathrm{kgK})$

$h \quad$ Heat transfer coefficient $\left(\mathrm{W} / \mathrm{m}^{2}{ }^{\circ} \mathrm{C}\right)$

I Solar radiation on the collector $\left(\mathrm{W} / \mathrm{m}^{2}\right)$

$\dot{m}_{a} \quad$ Air mass flow rate $(\mathrm{kg} / \mathrm{s})$

$Q_{u} \quad$ Useful heat of air (W)

SAC Solar air collector

$T \quad$ Temperature $\left({ }^{\circ} \mathrm{C}\right)$

\section{References}

[1]Huang MY, Wang MLi, Keovisar V, Li X, Kong D, Yu Q. "Comparative study on energy and exergy properties of solar photovoltaic/thermal air collector based on amorphous silicon cells". Applied Thermal Engineering, 185, 116376, 2021.

[2] Arslan E, Aktaş M. "4E analysis of infrared-convective dryer powered solar photovoltaic thermal collector". Solar Energy, 208, 46-57, 2020.

[3] Tagnamas Z, Lamsyehe H, Moussaoui H, Bahammou Y, Kouhila M, Idlimam A, Lamharrar A. "Energy and exergy analyses of carob pulp drying system based on a solar collector". Renewable Energy, 163, 495-503, 2021.

[4] Ceylan I, Gürel AE. "Solar-assisted fluidized bed dryer integrated with a heat pump for mint leaves". Applied Thermal Engineering, 106, 899-905, 2016.

[5] Akpinar EK, Koçyiĝit F. "Energy and exergy analysis of a new flat-plate solar air heater having different obstacles on absorber plates". Applied Energy, 87, 3438-3450, 2010.

[6] Tuncer AD, Khanlari A, Sözen A, Gürbüz EY, Şirin C, Gungor A. "Energy-exergy and enviro-economic survey of solar air heaters with various air channel modifications". Renewable Energy, 160, 67-85, 2020.

[7] Komolafe CA, Oluwaleye IO, Awogbemi O, Osueke CO. "Experimental investigation and thermal analysis of solar air heater having rectangular rib roughness on the absorber plate". Case Studies in Thermal Engineering, 14, $100442,2019$.

[8] Sudhakar P, Cheralathan M. "Thermal performance enhancement of solar air collector using a novel V-groove absorber plate with pin-fins for drying agricultural products: an experimental study". Journal of Thermal Analysis and Calorimetry, 140, 2397-2408, 2020.

[9] Norouzian R. The Palgrave Handbook of Applied Linguistics Research Methodology. 1nd ed. Palgrave Macmillan, London, Springer, 2018.

[10] Vafaei LE, Sah M. "Predicting efficiency of flat-plate solar collector using a fuzzy inference system". Procedia computer science, 120, 221-228, 2017.

[11] Çakmak G, Yıldız C. "The prediction of seedy grape drying rate using a neural network method". Computers and Electronics in Agriculture, 75(1), 132-138, 2011.

[12] Caner M, Gedik E, Keçebaş A. "Investigation on thermal performance calculation of two type solar air collectors using artificial neural network". Expert Systems with Applications, 38(3), 1668-1674, 2011.

[13] Ghritlahre HK, Prasad RK. Investigation of thermal performance of unidirectional flow porous bed solar air heater using MLP, GRNN, and RBF models of ANN technique". Thermal Science and Engineering Progress, 6 , 226-235, 2018.

[14] Holman JP. Experimental methods for engineers. Eight Edit, McGraw-Hill, New York, 2012.

[15] Acır A, Ata İ. "A study of heat transfer enhancement in a new solar air heater having circular type turbulators". Journal of the Energy Institute, 89, 606-616, 2016.

[16] Devecioglu AG, Oruc V. "Experimental investigation of thermal performance of a new solar air collector with porous surface". Energy Procedia. 113, 251-258, 2017.

[17] Acir A, Ata I, Canli ME. "Investigation of effect of the circular ring turbulators on heat transfer augmentation and fluid flow characteristic of solar air heater". Experimental Thermal and Fluid Science, 77, 45-54, 2016. https://doi.org/10.1016/j.expthermflusci.2016.04.012.

[18] Acır A, Canlı ME, Ata İ, Çakıroğlu R. "Parametric optimization of energy and exergy analyses of a novel solar air heater with grey relational analysis". Applied Thermal Engineering, 122, 330-338, 2017.

[19] Sreehari E, Pradeep Ghantasala GS. "Climate changes prediction using simple linear regression". Journal of Computational and Theoretical Nanoscience, 16, 655-658, 2019. 
[20] Mahaboob B, Praveen JP, Appa Rao BV, Harnath Y, Narayana C, Prakash GB. "A study on multiple linear regression using matrix calculus". Advances in Mathematics: Scientific Journal, 9, 4863-4872, 2020. 